\title{
Correction: Multiple sequence-directed possibilities provide a pool of nucleosome position choices in different states of activity of a gene
}

Vinesh Vinayachandran, Rama-Haritha Pusarla and Purnima Bhargava*

\section{Correction}

After publication of this work [1] we noticed that there was on inadvertent oversight due to which Figure 1
(Figure 5) and 2 (Figure 6) Legends were interchanged. While Figures and their captions are correct, Legends should have been interchanged and read as follows.
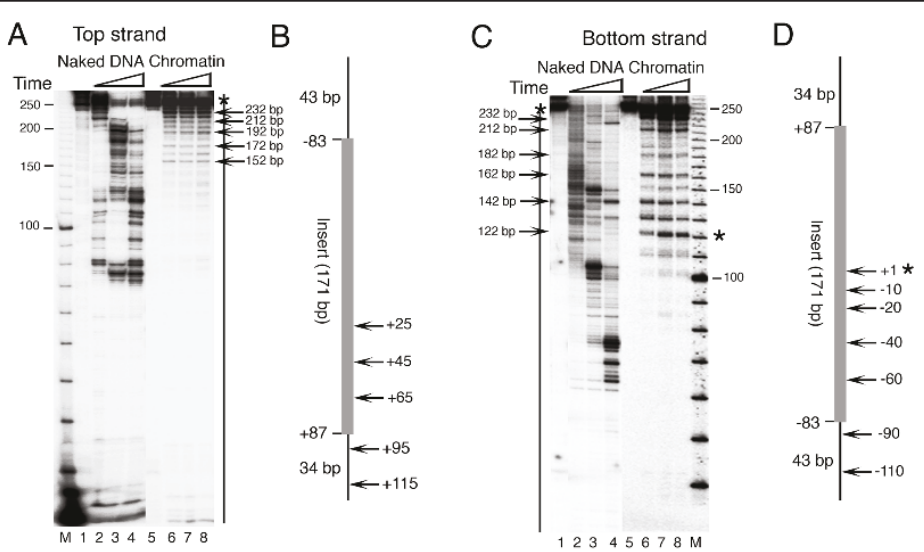

E 5 ' Half DNA (248 bp)

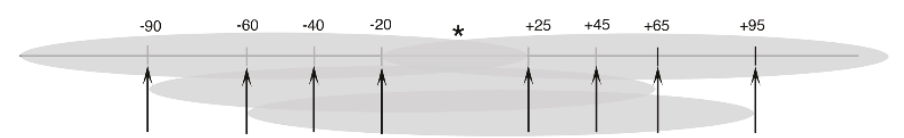

Figure 5 Exo III mapping of the nucleosomes on the 5' Half SNR6 DNA fragments. Chromatin was assembled on the 248 bp DNA fragments labeled at the $5^{\prime}$ end of either of the strands and digested by Exo III for different times. A 10 bp DNA ladder (Invitrogen) was end labeled and used as size marker in the lanes M. (A) Mapping on the top strand. Lanes 1 and 5 show uncut DNA; lanes 2-4 show naked DNA and 6-8 show chromatin. Sizes of the marker bands are given in the left hand side while arrows on the right hand side give the sizes of the DNA fragments due to the pauses of Exo III. (B) Schematic summary of mapping results from the panel A. Insert represents the cloned genomic DNA from -83 to +87 bp positions in the SNR6 gene while the flanking 43 and 34 bp are vector-derived DNA. The numbers on right hand site are the Exo III stops seen in the gel and represent the nucleosome boundaries. (C) Mapping on the bottom strand. Lanes 1 and 5 show uncut DNA; lanes 2-4 show naked DNA and 6-8 show chromatin. Sizes of the marker bands are given in the right hand side while arrows on the left hand side give the sizes of the DNA fragments due to the pauses of Exo III. (D) Schematic summary, similar to panel B, of the mapping results from the panel C. The numbers on right hand site are the Exo III stops seen in the gels and represent the nucleosome boundaries. (E) Schematic representation of mapping results on $5^{\prime}$ half DNA from both the strands. Ovals represent nucleosomes while arrows show positions of their boundaries and Exo III stops, marked in upper portion of the cartoon. An asterisk in panels C, D and E shows the position of Exo III stop in the middle of the DNA fragment, at +2 bp position of SNR6.

\footnotetext{
* Correspondence: purnima@ccmb.res.in

Centre for Cellular \& Molecular Biology (Council of Scientific and Industrial

Research) Uppal Road, Hyderabad-500007, India
}

(C) 2011 Vinayachandran et al; licensee BioMed Central Ltd. This is an Open Access article distributed under the terms of the Creative Commons Attribution License (http://creativecommons.org/licenses/by/2.0), which permits unrestricted use, distribution, and reproduction in any medium, provided the original work is properly cited. 


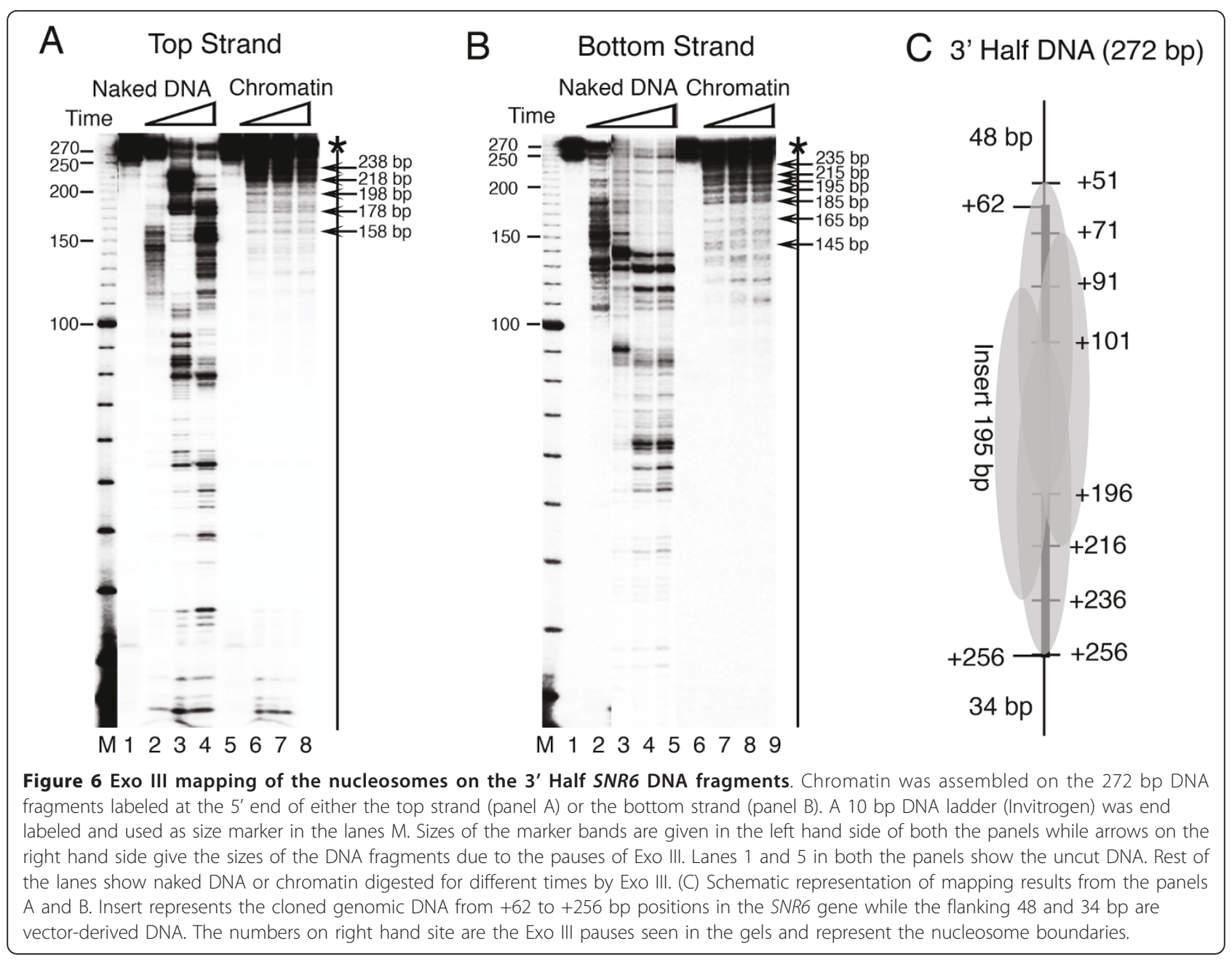

Received: 28 April 2011 Accepted: 7 May 2011 Published: 7 May 2011

\section{Reference}

1. Vinayachandran V, Haritha PR, Bhargava P: Multiple sequence-directed possibilities provide a pool of nucleosome position choices in different states of activity of a gene. Epigenetics and Chromatin 2009, 2:4.

doi:10.1186/1756-8935-4-8

Cite this article as: Vinayachandran et al: Correction: Multiple sequencedirected possibilities provide a pool of nucleosome position choices in different states of activity of a gene. Epigenetics \& Chromatin 2011 4:8.

\section{Submit your next manuscript to BioMed Central} and take full advantage of:

- Convenient online submission

- Thorough peer review

- No space constraints or color figure charges

- Immediate publication on acceptance

- Inclusion in PubMed, CAS, Scopus and Google Scholar

- Research which is freely available for redistribution 